\title{
Reclassification of Lactobacillus thermotolerans Niamsup et al. 2003 as a later synonym of Lactobacillus ingluviei Baele et al. 2003
}

Correspondence
F. Dellaglio
franco.dellaglio@univr.it

\author{
G. E. Felis, ${ }^{1,2}$ M. Vancanneyt, ${ }^{3}$ C. Snauwaert, ${ }^{3}$ J. Swings, ${ }^{3,4}$ S. Torriani, ${ }^{1}$ \\ A. Castioni ${ }^{1}$ and F. Dellaglio ${ }^{1}$ \\ ${ }^{1}$ Dipartimento Scientifico e Tecnologico, Università degli Studi di Verona, Strada le Grazie, 15, \\ I-37134 Verona, Italy \\ ${ }^{2}$ Dipartimento di Scienze Biomediche, Sezione di Microbiologia Sperimentale e Clinica, Viale \\ San Pietro 43b, I-07100 Sassari, Italy \\ ${ }^{3,4}$ BCCM/LMG Bacteria Collection ${ }^{3}$ and Laboratory of Microbiology ${ }^{4}$, Ghent University, \\ K. L. Ledeganckstraat 35, B-9000 Ghent, Belgium
}

Lactobacillus ingluviei Baele et al. 2003 was described as follows on the basis of the characteristics of seven strains isolated from pigeon crops and intestines. Cells are Grampositive (rapidly decolourizing in the Gram-stain procedure), non-motile, very short, plump rods that mostly occur singly or in pairs. Better growth is obtained at $42{ }^{\circ} \mathrm{C}$ than at 37 or $30^{\circ} \mathrm{C}$; no growth occurs at $25^{\circ} \mathrm{C}$. Acid is produced from $\mathrm{L}$-arabinose, $\mathrm{D}$-fructose, methyl $\beta$-xyloside, ribose, sucrose and D-xylose; fermentation of D-glucose, maltose, D-mannose, D-raffinose, gluconate and aesculin is variable. The DNA G $+\mathrm{C}$ content is $49 \mathrm{~mol} \%$. This species, based on 16S rRNA gene sequence analysis, belongs to the Lactobacillus reuteri phylogenetic group and highest sequences similarities were obtained to the sequences of Lactobacillus fermentum and Lactobacillus mucosae.

Lactobacillus thermotolerans Niamsup et al. 2003 was described on the basis of morphological, physiological and biochemical characteristics of five thermotolerant strains isolated from chicken faeces in Thailand. Cells are Grampositive, non-motile, non-spore-forming, catalase-negative rods, $1 \times 2-3 \mu \mathrm{m}$ in size, which occur singly, in pairs or as

The GenBank/EMBL/DDBJ accession numbers for the partial hsp60 gene sequences of $L$. ingluviei LMG $20380^{\top}$ and $L$. thermotolerans DSM $14792^{\top}$ are respectively AJ621722 and AJ621723 and the accession numbers for the partial rec $A$ gene sequences of $L$. ingluviei LMG $20380^{\top}$ and L. thermotolerans DSM $14792^{\top}$ are respectively AJ972423 and AJ621677. short chains. Obligately heterofermentative, they produce both D- and L-lactic acid isomers. Growth is observed up to $50{ }^{\circ} \mathrm{C}$, but not at $15^{\circ} \mathrm{C}$ (the optimum temperature is $42^{\circ} \mathrm{C}$ ). meso-Diaminopimelic acid is not present in the cell wall and the DNA G + C content of the type strain is $50.5 \mathrm{~mol} \%$.

A comparative sequence analysis based on 16S rRNAencoding genes obtained from GenBank (accession numbers $\mathrm{AF} 333975$ for L. ingluviei $\mathrm{KR}^{\mathrm{T}}$ and AF317702 for L. thermotolerans $\mathrm{G} 35^{\mathrm{T}}$ ) revealed very high similarity; only two nucleotides were found to be different $(99 \cdot 87 \%$ similarity over a total of $1504 \mathrm{bp}$ ). Moreover, the physiological traits reported by the authors, the habitats from which these bacteria have been isolated and the observation that the two species were described in the same year (and no reciprocal comparison was therefore made) suggest the necessity of clarifying their taxonomic relationship with additional genetic approaches.

L. ingluviei LMG $20380^{\mathrm{T}}$ and L. thermotolerans DSM $14792^{\mathrm{T}}$ $\left(=\right.$ LMG $22056^{\mathrm{T}}$ ) were grown in MRS broth at $37^{\circ} \mathrm{C}$ under anaerobiosis and bacterial cultures were checked for purity.

In order to look at the difference between the two species, two protein-encoding genes, $h s p 60$ and $r e c A$, were sequenced and compared. It has already been reported that sequences of protein-encoding genes have higher discriminatory power than 16S rRNA gene sequences (Felis et al., 2001; Rosselló-Mora \& Amann, 2001). Sequence comparison of 
these genes has proven to be helpful to describe the relationships among closely related taxa (Felis et al., 2001; Torriani et al., 2001; Dellaglio et al., 2004, 2005; Bringel et al., 2005), although no threshold of sequence similarity for these protein-encoding genes has yet been proposed.

DNA of type strains LMG $20380^{\mathrm{T}}$ and DSM $14792^{\mathrm{T}}$ was extracted following the procedure of Marmur (1961). Partial hsp60 gene sequences were amplified using two degenerate primers, cpn-f and cpn-r, as described by Dellaglio et al. (2005) and amplification products of about $1000 \mathrm{bp}$ were obtained. Sequencing reactions were performed at the Biomolecular Research Centre (BMR), University of Padua, Italy, with the primers used during the PCR. Sequences of $954 \mathrm{bp}$, representing about the $57 \%$ of the complete gene (considering the complete $h s p 60$ gene sequences NT01LP0651 and NT01LJ0492 of the genome sequences of Lactobacillus plantarum WCSF1 and Lactobacillus johnsonii NCC 533, respectively), were obtained for the two type strains and compared. A total of 11 nucleotides were found to be different.

Partial $r e c A$ gene sequences were obtained using the degenerate primers recEXT- $\mathrm{f}$ and recEXT1- $\mathrm{r}$ as described by Dellaglio et al. (2005). Thermal conditions were optimized to improve amplification efficiency as follows: an initial denaturation of $5 \mathrm{~min}$ at $94^{\circ} \mathrm{C}, 35$ cycles of $45 \mathrm{~s}$ at $94^{\circ} \mathrm{C}$, $120 \mathrm{~s}$ at $50^{\circ} \mathrm{C}$ and $105 \mathrm{~s}$ at $72{ }^{\circ} \mathrm{C}$ and a final extension at $72^{\circ} \mathrm{C}$ for $7 \mathrm{~min}$. PCR products of $750 \mathrm{bp}$, about half of the complete gene sequence considering the complete recA gene of L. plantarum WCSF1 and L. johnsonii NCC 533, were obtained for the L. ingluviei and $L$. thermotolerans type strains. Sequence comparison revealed seven differences from a total of $452 \mathrm{bp}$.

In order to clarify the taxonomic status of the two species further, a DNA-DNA hybridization test was performed between the two type strains L. ingluviei LMG $20380^{\mathrm{T}}$ and $L$. thermotolerans LMG $22056^{\mathrm{T}}$ and their $\mathrm{G}+\mathrm{C}$ contents were redetermined. For strain LMG $20380^{\mathrm{T}}$, DNA was extracted from $0 \cdot 75-1.25 \mathrm{~g}$ wet weight of cells using the protocol described by Pitcher et al. (1989) with the following modifications: the washed cell pellet was resuspended and lysed in a buffer (10 mM Tris/HCl, 100 mM EDTA, pH 8.0) containing RNase $\left(200 \mu \mathrm{g} \mathrm{ml}^{-1}\right.$; Sigma $)$, mutanolysin $\left(100 \mathrm{U} \mathrm{ml}^{-1}\right.$; Sigma) and lysozyme ( $25 \mathrm{mg} \mathrm{ml}^{-1}$; SERVA) for $1 \mathrm{~h}$ at $37^{\circ} \mathrm{C}$. Before addition of GES reagent ( $5 \mathrm{M}$ guanidine thiocyanate, $100 \mathrm{nM}$ EDTA, $0.5 \%$ Sarkosyl in water), proteinase $\mathrm{K}$ $\left(200 \mu \mathrm{g} \mathrm{ml}^{-1}\right.$; Merck) was added to the mixture for $15 \mathrm{~min}$. For strain LMG $22056^{\mathrm{T}}$, DNA was extracted from 0.75$1 \cdot 25 \mathrm{~g}$ wet weight of cells by using the protocol described by Gevers et al. (2001), using a combination of glass beads and enzymes, but with the following modifications. Volumes were increased tenfold for application on a large scale. SDS-treated cells were vortexed with beads for $30 \mathrm{~s}$. After addition and gentle shaking with $16.5 \mathrm{ml}$ buffer $(10 \mathrm{mM}$ Tris/HCl, $100 \mathrm{mM}$ EDTA, pH 8.0) and $5 \mathrm{ml} 5 \mathrm{M} \mathrm{NaCl}$, the suspension was incubated at $65{ }^{\circ} \mathrm{C}$ for $10 \mathrm{~min}$. Subsequent chloroform/isoamyl alcohol extraction, precipitation, spooling of DNA on a glass rod, washing with ethanol and RNase treatment was performed as described by Marmur (1961). For DNA-DNA hybridizations, the microplate method was used as described by Ezaki et al. (1989) and Goris et al. (1998) using an HTS7000 Bio Assay Reader (Perkin Elmer) for fluorescence measurements. Biotinylated DNA was hybridized with unlabelled single-stranded DNA, which was bound non-covalently to microplate wells. Hybridizations were performed at $41{ }^{\circ} \mathrm{C}$ in hybridization mixture $(2 \times$ SSC, $5 \times$ Denhardt's solution, $2.5 \%$ dextran sulphate, $50 \%$ formamide, $100 \mu \mathrm{g}$ denatured salmon sperm DNA $\mathrm{ml}^{-1}, 1 \cdot 25 \mu \mathrm{g}$ biotinylated probe DNA $\mathrm{ml}^{-1}$ ). The percentage DNA relatedness presented is a mean value, based on four independent hybridization experiments. Reciprocal reactions (i.e. $\mathrm{A} \times \mathrm{B}$ and $\mathrm{B} \times \mathrm{A}$ ) were performed and are also considered as independent hybridization experiments.

For determination of the DNA G $+\mathrm{C}$ content, DNA was enzymically degraded into nucleosides as described by Mesbah et al. (1989). The nucleoside mixture was then separated by HPLC using a Waters SymmetryShield C8 column maintained at a temperature of $37^{\circ} \mathrm{C}$. The solvent was $0.02 \mathrm{M}\left(\mathrm{NH}_{4}\right) \mathrm{H}_{2} \mathrm{PO}_{4}(\mathrm{pH} 4 \cdot 0)$ with $1.5 \%$ acetonitrile. Non-methylated $\lambda$ phage DNA (Sigma) was used as the calibration reference.

Results showed that the type strains of $L$. ingluviei and $L$. thermotolerans had a binding level of $79 \pm 3 \%$; consequently, as currently delineated (Rosselló-Mora \& Amann, 2001; Stackebrandt \& Goebel, 1994), the two species constitute a single taxonomic unit. The $\mathrm{G}+\mathrm{C}$ contents of the type strains were $50 \mathrm{~mol} \%$ for L. ingluviei LMG $20380^{\mathrm{T}}$ and $49 \mathrm{~mol} \%$ for L. thermotolerans DSM $14792^{\mathrm{T}}$.

Considering the high value of total DNA hybridization obtained, the possibility of describing two subspecies was evaluated to group strains of the two former species. Therefore, a few fermentation tests were performed: data reported in the original species descriptions were compared and it was found that melibiose was fermented by $L$. thermotolerans but not by L. ingluviei. Both species are able to metabolize D-fructose and not lactose. These experiments were repeated by growing L. ingluviei LMG $20380^{\mathrm{T}}$ and $L$. thermotolerans DSM $14792^{\mathrm{T}}$ at $30^{\circ} \mathrm{C}$ for $24-48 \mathrm{~h}$ in phenol red medium broth with lactose, melibiose or fructose $(1 \%$ final concentration) added as the sole carbon source. Lactose and fructose were used as negative and positive controls, respectively. The two type strains yield identical metabolic profiles, as both metabolized fructose, but neither fermented melibiose or lactose, in contrast to the description of the species L. thermotolerans (Niamsup et al., 2003).

Although the two species were isolated from slightly different environments (pigeons and chickens) and from very distant places (Europe and Asia) and display sequences of two protein-encoding genes that are not identical, the delineation of intraspecific clusters was not considered in this study. Therefore it is proposed that the two species 
Lactobacillus ingluviei and Lactobacillus thermotolerans should be united under the same name. According to the rules of priority (Rules 38 and 42 of the Bacteriological Code; Lapage et al., 1992), the name Lactobacillus ingluviei should be retained with its type strain KR3 $3^{\mathrm{T}}\left(=\right.$ CCUG $45722^{\mathrm{T}}=$ DSM $\left.15946^{\mathrm{T}}=\mathrm{JCM} 12531^{\mathrm{T}}=\mathrm{LMG} 20380^{\mathrm{T}}\right)$. Consequently, strains of $L$. thermotolerans should be reclassified as belonging to L. ingluviei. Due to the very similar traits reported in the descriptions of the two species, an emended description of $L$. ingluviei is not considered necessary. The species $L$. ingluviei belongs to the $L$. reuteri phylogenetic group within the genus Lactobacillus as delineated by Hammes \& Hertel (2003).

\section{Acknowledgements}

M. V., C.S. and J.S. acknowledge the support of the Belgian Federal Public Planning Service - Science Policy.

\section{References}

Baele, M., Vancanneyt, M., Devriese, L. A., Lefebvre, K., Swings, J. \& Haesebrouck, F. (2003). Lactobacillus ingluviei sp. nov., isolated from the intestinal tract of pigeons. Int J Syst Evol Microbiol 53, 133-136.

Bringel, F., Castioni, A., Olukoya, D. K., Felis, G. E., Torriani, S. \& Dellaglio, F. (2005). Lactobacillus plantarum subsp. argentoratensis subsp. nov., isolated from vegetable matrices. Int $J$ Syst Evol Microbiol 55, 1629-1634.

Dellaglio, F., Torriani, S. \& Felis, G. E. (2004). Reclassification of Lactobacillus cellobiosus Rogosa et al. 1953 as a later synonym of Lactobacillus fermentum Beijerinck 1901. Int J Syst Evol Microbiol 54, 809-812.

Dellaglio, F., Felis, G. E., Castioni, A., Torriani, S. \& Germond, J.-E. (2005). Lactobacillus delbrueckii subsp. indicus subsp. nov., isolated from Indian dairy products. Int J Syst Evol Microbiol 55, 401-404.

Ezaki, T., Hashimoto, Y. \& Yabuuchi, E. (1989). Fluorometric deoxyribonucleic acid-deoxyribonucleic acid hybridization in microdilution wells as an alternative to membrane filter hybridization in which radioisotopes are used to determine genetic relatedness among bacterial strains. Int J Syst Bacteriol 39, 224-229.
Felis, G. E., Dellaglio, F., Mizzi, L. \& Torriani, S. (2001). Comparative sequence analysis of a $\operatorname{rec} A$ gene fragment brings new evidence for a change in the taxonomy of the Lactobacillus casei group. Int J Syst Evol Microbiol 51, 2113-2117.

Gevers, D., Huys, G. \& Swings, J. (2001). Applicability of rep-PCR fingerprinting for differentiation of Lactobacillus species. FEMS Microbiol Lett 205, 31-36.

Goris, J., Suzuki, K., De Vos, P., Nakase, T. \& Kersters, K. (1998). Evaluation of a microplate DNA-DNA hybridization method compared with the initial renaturation method. Can J Microbiol 44, 1148-1153.

Hammes, W. P. \& Hertel, C. (2003). The genera Lactobacillus and Carnobacterium. In The Prokaryotes. An Evolving Electronic Resource for the Microbiological Community, release 3.15. Edited by $\mathrm{M}$. Dworkin and others. http://141.150.157.117:8080/prokPUB/index.htm

Lapage, S. P., Sneath, P. H. A., Lessel, E. F., Skerman, V. B. D., Seelinger, H. P. R. \& Clark, W. A. (editors) (1992). International Code of Nomenclature of Bacteria (1990 Revision). Bacteriological Code. Washington, DC: American Society for Microbiology.

Marmur, J. (1961). A procedure for the isolation of DNA from microorganisms. J Mol Biol 3, 208-218.

Mesbah, M., Premachandran, U. \& Whitman, W. B. (1989). Precise measurement of the $\mathrm{G}+\mathrm{C}$ content of deoxyribonucleic acid by high-performance liquid chromatography. Int J Syst Bacteriol 39, 159-167.

Niamsup, P., Sujaya, I. N., Tanaka, M. \& 8 other authors (2003). Lactobacillus thermotolerans sp. nov., a novel thermotolerant species isolated from chicken faeces. Int J Syst Evol Microbiol 53, 263-268.

Pitcher, D. G., Saunders, N. A. \& Owen, R. J. (1989). Rapid extraction of bacterial genomic DNA with guanidium thiocyanate. Lett Appl Microbiol 8, 151-156.

Rossello-Mora, R. \& Amann, R. (2001). The species concept for prokaryotes. FEMS Microbiol Rev 25, 39-67.

Stackebrandt, E. \& Goebel, B. M. (1994). Taxonomic note: a place for DNA-DNA reassociation and 16S rRNA sequence analysis in the present species definition in bacteriology. Int J Syst Bacteriol 44, 846-849.

Torriani, S., Felis, G. E. \& Dellaglio, F. (2001). Differentiation of Lactobacillus plantarum, L. pentosus and L. paraplantarum by recA gene sequence analysis and multiplex PCR assay with recA genederived primers. Appl Environ Microbiol 67, 3450-3454. 